\title{
Dynamics of bee communities (Hymenoptera: Apoidea: Apiformes) in heath and grassland patches during secondary succession of the Peucedano-Pinetum series in the Torun Basin
}

\author{
Tadeusz Pawlikowski
}

Laboratory for Biomonitoring of Terrestrial Environments, Institute of Ecology \& Environmental Protection, Nicolaus Copernicus University, Gagarina 9, 87-100 Torun, Poland, e-mail: pawlik@biol.uni.torun.pl

\begin{abstract}
Structural dynamics of bee communities was described in the heath area subject to succession of coniferous forest $P e u-$ cedano-Pinetum. As pine trees successively overgrew the area, two-threefold decrease in the number of species was observed. Flowering of heather increased the food attractiveness of the heath for species of social bees. Stabilization of the structure of bee communities in the heath was observed as a consequence of placing a portable apiary.
\end{abstract}

Key words: Hymenoptera, Apiformes, bee communities, secondary succession, Peucedano-Pinetum series, Toruń Basin.

\section{Introduction}

Grasslands and heaths of sandy habitats developed in historical times as a result of human cultural activities. Their frequent occurrence is related to inland dunes in river valleys. And there, they are being transformed into xerothermic habitats, which are then being settled with bees (Apiformes), following the encroachment of flowering vegetation. This taxon comprises very active phytophagous species specialized in collection of pollen and nectar from flowering plants (Pawlikowski \& Kruszyński 1997). In terrestrial environments, they form communities of multispecies populations competing for resources (i.e. food and space for reproduction) within a biocoenosis, or within a complex of biocoenoses in a given landscape.

In the eighties and the nineties, communities of bees were studied in the Torun Basin regarding the processes of succession and development on dune grasslands (Pawlikowski 1985), as well as in forest monocultures (Pawlikowski 1992). In this research, however, no proper attention was given to the significance of grassland and heath patches for the establishment of bee communities during succession of biocoenoses from the Peucedano-Pinetum series. Habitats of this series predominate in the Torun Basin. Therefore, materials from the 1980s were used and they were worked out in detail as a separate subject, not undertaken previously. This study presents it as transformations of the structure and functions of xerothermophilous communities of phytophagous species during succession of their habitat biocoenoses.

\section{Material and Methods}

The research was carried out in 1984-1985 within the heath area and adjacent, open dry pine forests on the southern outskirts of the administrative boundaries of the city of Toruń, within the Torun Basin (North Poland, UTM: CD37). The dominating potential forest association of the studied area is pine forest Peucedano-Pinetum (Kępczyński 1980). The real vegetation comprises heath patches accompanied by patches of dune grasslands, which are subject 
Table 1. Stands under secondary succession of the Peucedano-Pinetum series in the Torun Basin

\begin{tabular}{|l|c|l|c|c|}
\hline \multirow{2}{*}{\multicolumn{1}{|c|}{ Stand }} & \multicolumn{3}{|c|}{ Vegetation } & \multicolumn{2}{c|}{ Pinus sylvestris } \\
\cline { 2 - 5 } & $\begin{array}{c}\text { area } \\
{[\text { ha] }}\end{array}$ & \multicolumn{1}{c|}{ paths } & $\begin{array}{c}\text { covering } \\
{[\%]}\end{array}$ & $\begin{array}{c}\text { age } \\
{[\text { years] }}\end{array}$ \\
\hline Young coppice [YF] & 5 & $\begin{array}{l}\text { grass-stand of Corynephorus canescens, heath of Arctostaphyllo- } \\
\text { Callunetum }\end{array}$ & $15-25$ & $4-5$ \\
\hline Developed coppice [TF] & 2 & $\begin{array}{l}\text { grass-stand of Corynephorus canescens, heath of Arctostaphylo- } \\
\text { Callunetum }\end{array}$ & 50 & $10-15$ \\
\hline Forest stand [AF] & 5 & $\begin{array}{l}\text { grass-stand with Deschampsia flexuosa and Convallaria majalis, } \\
\text { heath with Calluna vulgaris }\end{array}$ & 90 & 70 \\
\hline
\end{tabular}

to spontaneous pine spreading (Pinus sylvestris L.) and get transformed into multiage young growths (Pawłowski \& Zarzycki 1972; Symonides 1974). Whereas, the same patches in contiguous pine forests have been and still are subject to forest management. In these developmentally heterogeneous areas, three locations were selected, representing succession and developmental states of the forest association Peucedano-Pinetum (Tab. 1). During the vegetation season of 1984, a portable, ca. fifty-hive apiary was placed in the vicinity of the heath. At the time of heather blooming, the apiary was placed directly at the sites of young forest stands (YF and TF).

The materials were being obtained at the sites from April till September. The number of bees caught alive by an entomological net and recorded during a 30 min walk at a given site along a transect of $200 \mathrm{~m}$ long was accepted as a sample. Samples of long-tongued bees were collected in optimal weather conditions (nice weather, air temperature of $19-25^{\circ} \mathrm{C}$ ) between 9 a.m. and 3 p.m. of Central-European Time. Also flowering phenology was recorded for plants most frequently visited by bees (Tab. 2).

Altogether 1520 specimens of wild bees and 1066 workers of Apis mellifera L. were recorded in the study area, and they were included in the description of communities. In the structure of a community, the number of species $(S)$, seasonal dynamics of the count, general species diversity $\left(H^{\prime}\right)$ and evenness $\left(J^{\prime}\right)$ were defined. The formula of the general species diversity index was accepted after Shannon (Shannon \& Weaver 1963): $H^{\prime}=-\sum p_{i} \log _{2} p_{i}$, where $p_{i}=n_{i} / N$, which means a dominant fraction of the $i$-th species in a community consisting of $S$ species, and $N$ is a general number of all species. In order to define evenness of the communities, the index of Pielou (1966) was applied: $J^{\prime}=H^{\prime} / H^{\prime}{ }_{\max }$, where value $H^{\prime}{ }_{\max }=\log _{2} S$. The in$\operatorname{dex} J^{\prime}$ assumes values within the range of $0<J^{\prime}<1$, while decreasing the value till 0 means the increasing tendency of super-domination, and increasing the value up to 1 means the increasing tendency of co-domination.
Density of bees within each site was compared based on the t-test. Statistical significance of a difference between $H^{\prime}$ values was assessed according to Hutcheson (1970). Significance of a difference was accepted at the level of $P \leq 0.05$.

\section{Results and discussion}

Altogether 97 bee species were recorded at the selected sites (Pawlikowski 1992). In the succession and developmental sequence of the site with heather patches starting from a young coppice forest (YF), through a developed coppice forest (TF) until a forest stand (AF), the number of species was decreasing. This decrease proceeded in the approximate ratio of $2: 1: 1$ in 1984 and $3: 1: 1$ in 1985 (Tab. 3). On the other hand, average density changed according to the ratio of $5: 4: 1$ in 1984 and $7: 7: 1$ in 1985.

General species diversity $\left(H^{\prime}\right)$ remained at a similar level (3.10-3.12) in 1984 and at a significantly different $(\mathrm{P} \leq 0.05)$ level regarding the decrease of values $(4.18-$ $2.74)$ in 1985 . In 1984 the evenness index of quantitative distribution of species in a community $\left(J^{\prime}\right)$ demonstrated the stability in species' contribution at the stage of thicket phases of the heath and co-domination at the stage of mature tree stands. Whereas, in 1985 this index oscillated within a very similar range of values in all communities of succession- developmental phases, i.e. at the co-domination level (Tab. 5).

Successive overgrowing of the heath by forest in dune fields of the Torun Basin decreased its habitat attractiveness for bees. As the heath area has been successively overgrown by pine, two- threefold decrease in the number of species was observed. Blooming of heather increased the food attractiveness of heath and grassland patches for species of social bees, especially bumblebees (Tab. 4). Furthermore, it enriched the structure of communities with 
Table 2. Full flowering phenology of plants most frequent visited by bees in grassland and heath paths of the Peucedano-Pinetum series in the Toruń Basin during 1984-1985

\begin{tabular}{|c|c|c|c|c|c|c|c|c|c|c|c|c|c|c|c|c|}
\hline \multirow{3}{*}{ Species } & \multicolumn{16}{|c|}{ Months } \\
\hline & \multicolumn{2}{|c|}{ A } & \multicolumn{3}{|c|}{ M } & \multicolumn{3}{|c|}{$\mathrm{J}$} & \multicolumn{3}{|c|}{$\mathrm{J}$} & \multicolumn{3}{|c|}{ A } & \multicolumn{2}{|r|}{$\mathrm{S}$} \\
\hline & $\mathrm{x}$ & $\mathrm{x}$ & & & & & & & & & & & & & & \\
\hline Spergula morisonii Boreau & & $\mathrm{x}$ & $\mathrm{x}$ & & & & & & & & & & & & & \\
\hline Potentilla arenaria Borkh. & & $\mathrm{x}$ & $\mathrm{x}$ & $\mathrm{x}$ & $\mathrm{x}$ & & & & & & & & & & & \\
\hline Hieracium pilosella $\mathrm{L}$. & & & $\mathrm{x}$ & $\mathrm{x}$ & $\mathrm{x}$ & $\mathrm{x}$ & & & & & & & & & & \\
\hline Sedum acre L. & & & & & & $\mathrm{x}$ & $\mathrm{x}$ & $\mathrm{x}$ & & & & & & & & \\
\hline Scleranthus perennis L. & & & & & & $\mathrm{x}$ & $\mathrm{x}$ & $\mathrm{x}$ & $\mathrm{x}$ & & & & & & & \\
\hline Potentilla argentea L. s. str. & & & & & & $\mathrm{x}$ & $\mathrm{x}$ & $\mathrm{x}$ & $\mathrm{x}$ & $\mathrm{x}$ & $\mathrm{x}$ & & & & & \\
\hline Echium vulgare L. & & & & & & & & $\mathrm{x}$ & $\mathrm{x}$ & $\mathrm{X}$ & $\mathrm{x}$ & $\mathrm{x}$ & $\mathrm{x}$ & & & \\
\hline Peucedanum oreoselinum (L.) Moench & & & & & & & & & $\mathrm{x}$ & $\mathrm{X}$ & $\mathrm{x}$ & & & & & \\
\hline Thymus serpyllum L. emend. Fr. & & & & & & & & & $\mathrm{x}$ & $\mathrm{x}$ & $\mathrm{x}$ & $\mathrm{x}$ & & & & \\
\hline Centaurea stoebe L. & & & & & & & & & $\mathrm{x}$ & $\mathrm{x}$ & $\mathrm{x}$ & $\mathrm{x}$ & $\mathrm{x}$ & $\mathrm{x}$ & & \\
\hline Melampyrum pratense L. & & & & & & & & & & $\mathrm{x}$ & $\mathrm{x}$ & $\mathrm{x}$ & $\mathrm{x}$ & & & \\
\hline Tragopogon pratensis L. s. str. & & & & & & & & & & $\mathrm{X}$ & $\mathrm{X}$ & $\mathrm{x}$ & $\mathrm{x}$ & & & \\
\hline Helichrysum arenarium (L.) Moench & & & & & & & & & & & $\mathrm{x}$ & $\mathrm{x}$ & $\mathrm{x}$ & $\mathrm{x}$ & & \\
\hline Calluna vulgaris (L.) Hull & & & & & & & & & & & & & $\mathrm{x}$ & $\mathrm{x}$ & $\mathrm{x}$ & $\mathrm{x}$ \\
\hline
\end{tabular}

Table 3. Characteristics of the bee communities in grassland and heath paths of the Peucedano-Pinetum series (YF, TF, AF as in tab. 1) in the Toruń Basin during 1984-1985 (according to Pawlikowski 1992)

\begin{tabular}{|c|c|c|c|c|c|c|}
\hline \multirow{3}{*}{ Parameters } & \multicolumn{6}{|c|}{ Stands } \\
\hline & \multicolumn{3}{|c|}{1984} & \multicolumn{3}{|c|}{1985} \\
\hline & YF & $\mathrm{TF}$ & $\mathrm{AF}$ & YF & $\mathrm{TF}$ & $\mathrm{AF}$ \\
\hline Number of species & 30 & 14 & 14 & 33 & 10 & 10 \\
\hline $\begin{array}{l}\text { Abundance } \\
\text { [specimens } / 200 \mathrm{~m}^{2} / 30 \mathrm{~min} \text { ] }\end{array}$ & $21.04^{\mathrm{a}}$ & $16.20^{\mathrm{ab}}$ & $3.69^{\mathrm{b}}$ & 13.72 & $14.95^{\mathrm{c}}$ & $2.17^{\mathrm{c}}$ \\
\hline $\begin{array}{l}\text { Species diversity } \\
\text { [Shannon's index] }\end{array}$ & 3.11 & 3.10 & 3.12 & $4.18^{\mathrm{d}}$ & $3.66^{\mathrm{de}}$ & $2.74^{\mathrm{e}}$ \\
\hline $\begin{array}{l}\text { Evenness } \\
\text { [Pielou' index] }\end{array}$ & 0.64 & 0.67 & 0.82 & 0.83 & 0.82 & 0.83 \\
\hline
\end{tabular}

a-e) Significance level $P \leq 0.05$.

relatively numerous oligolectic species: Colletes succinctus and Andrena fuscipes.

In the analysis of seasonal dynamics of communities (Fig. 1), the influence of honeybees (from portable apiaries) on functional conditions of bee communities becomes par- ticularly apparent. Undoubtedly, placing the apiary in 1984 in the vicinity and within the heathland maintained the whole structure of communities at a more stable level from the functional point of view ( $J$ ' values closer to the value of 0.5$)$ as compared with the next year (without the portable apiary). 
Table 4. Bees most frequent visited flowering plants in habitats of the Peucedano-Pinetum series: YF - young coppice, TF - developed coppice, AF - forest stand

\begin{tabular}{|c|c|c|c|c|c|c|c|c|c|c|c|c|c|c|c|}
\hline \multirow{2}{*}{ Species of bees } & \multicolumn{15}{|c|}{ Visited plants (numbers according to Tab. 1) } \\
\hline & 1 & 2 & 3 & 4 & 5 & 6 & 7 & 8 & 9 & 10 & 11 & 12 & 13 & 14 & 15 \\
\hline Colletes cunicularius (L.) & $\mathrm{TF}$ & & & & & & & & & & & & & & \\
\hline C. daviesanus $\mathrm{Sm}$. & & & & & & & & & & & & & & YF & \\
\hline C. succinctus (L.)* & & & & & & & & & & & & & & & $\begin{array}{l}\text { YF } \\
\text {-AF }\end{array}$ \\
\hline C. marginatus $\mathrm{Sm}$. & & & & & YF & & & & $\mathrm{AF}$ & & & & & & \\
\hline Hylaeus communis Nyl. & & & & & YF & & & & $\begin{array}{l}\text { YF } \\
\mathrm{AF}\end{array}$ & & & & & & $\mathrm{AF}$ \\
\hline Andrena barbilabris (K.) & $\mathrm{TF}$ & YF & $\begin{array}{l}\text { YF } \\
\text { TF }\end{array}$ & & & & & & & & & & & & \\
\hline A. bimaculata $(\mathrm{K})$. & $\mathrm{TF}$ & & & & & & & & & & & & & & \\
\hline A. falsifica Perk. & & $\mathrm{AF}$ & $\begin{array}{l}\text { YF } \\
\text { TF }\end{array}$ & & & & & & & & & & & & \\
\hline A. flavipes Pz. & $\mathrm{TF}$ & & & & & & & & & & & & & & \\
\hline A. fuscipes (K.)* & & & & & & & & & & & & & & & $\begin{array}{l}\text { YF } \\
\text { TF }\end{array}$ \\
\hline A. haemorrhoa (F.) & $\mathrm{TF}$ & $\mathrm{AF}$ & $\begin{array}{l}\text { YF } \\
\text { TF }\end{array}$ & & & & & & & & & & & & \\
\hline A. praecox (Scop.) & $\mathrm{TF}$ & & $\begin{array}{l}\mathrm{YF} \\
\mathrm{TF}\end{array}$ & & & & & & & & & & & & \\
\hline A. vaga Pz. & $\mathrm{TF}$ & & $\begin{array}{l}\text { YF } \\
\text { TF }\end{array}$ & & & & & & & & & & & & \\
\hline A. ventralis $\mathrm{Im}$. & & YF & & & & & & & & & & & & & \\
\hline Halictus confusus perkinsi $\mathrm{B} 1$. & & YF & $\begin{array}{l}\text { YF } \\
\text { TF }\end{array}$ & & & $\mathrm{TF}$ & $\begin{array}{l}\text { YF } \\
\text { TF }\end{array}$ & & YF & & & & & & \\
\hline H. tumulorum (L.) & & YF & $\mathrm{AF}$ & YF & & $\begin{array}{l}\text { YF } \\
\text { TF }\end{array}$ & $\begin{array}{l}\mathrm{TF} \\
\mathrm{AF}\end{array}$ & & YF & & & & & $\begin{array}{l}\text { YF } \\
\text { TF }\end{array}$ & \\
\hline Lasioglossum lucidulum (Sc.) & & & & & & $\mathrm{TF}$ & $\mathrm{TF}$ & & & & & & & & \\
\hline L. leucozonium (Schranck) & & & $\mathrm{AF}$ & $\begin{array}{l}\text { YF } \\
\text { TF }\end{array}$ & & & YF & & & & & & & & \\
\hline L. punctatissimum (Sc.) & & $\mathrm{AF}$ & & & $\mathrm{TF}$ & $\mathrm{TF}$ & YF & & & & & & & & \\
\hline L. sexstrigatum (Sc.) & & & & & $\mathrm{TF}$ & $\mathrm{TF}$ & YF & & & & & & & & \\
\hline Dasypoda altercator (Harris) & & & & & & & & & & & & & YF & & \\
\hline Heliophila bimaculata (Pz.) & & & & & & & & YF & & $\begin{array}{l}\text { TF } \\
\mathrm{AF}\end{array}$ & YF & & & & \\
\hline Bombus lapidarius (L.) & & & & & YF & & & YF & & $\mathrm{TF}$ & YF & & & & YF \\
\hline B. lucorum (L.) & & & & & & & & YF & & $\begin{array}{l}\mathrm{TF} \\
\mathrm{AF}\end{array}$ & YF & YF & & & YF \\
\hline B. pascuorum (Scop.) & & & & & & & & YF & & & YF & & & & YF \\
\hline B. ruderarius (Müll.) & & & YF & & & & & YF & & YF & & & & & YF \\
\hline B. terrestris (L.) & & & YF & & & & & YF & & TF & YF & YF & YF & & YF \\
\hline Number of bee species & 7 & 7 & 10 & 2 & 5 & 5 & 6 & 6 & 4 & 5 & 5 & 2 & 2 & 2 & 8 \\
\hline
\end{tabular}

*) Oligolectic on Calluna vulgaris. 

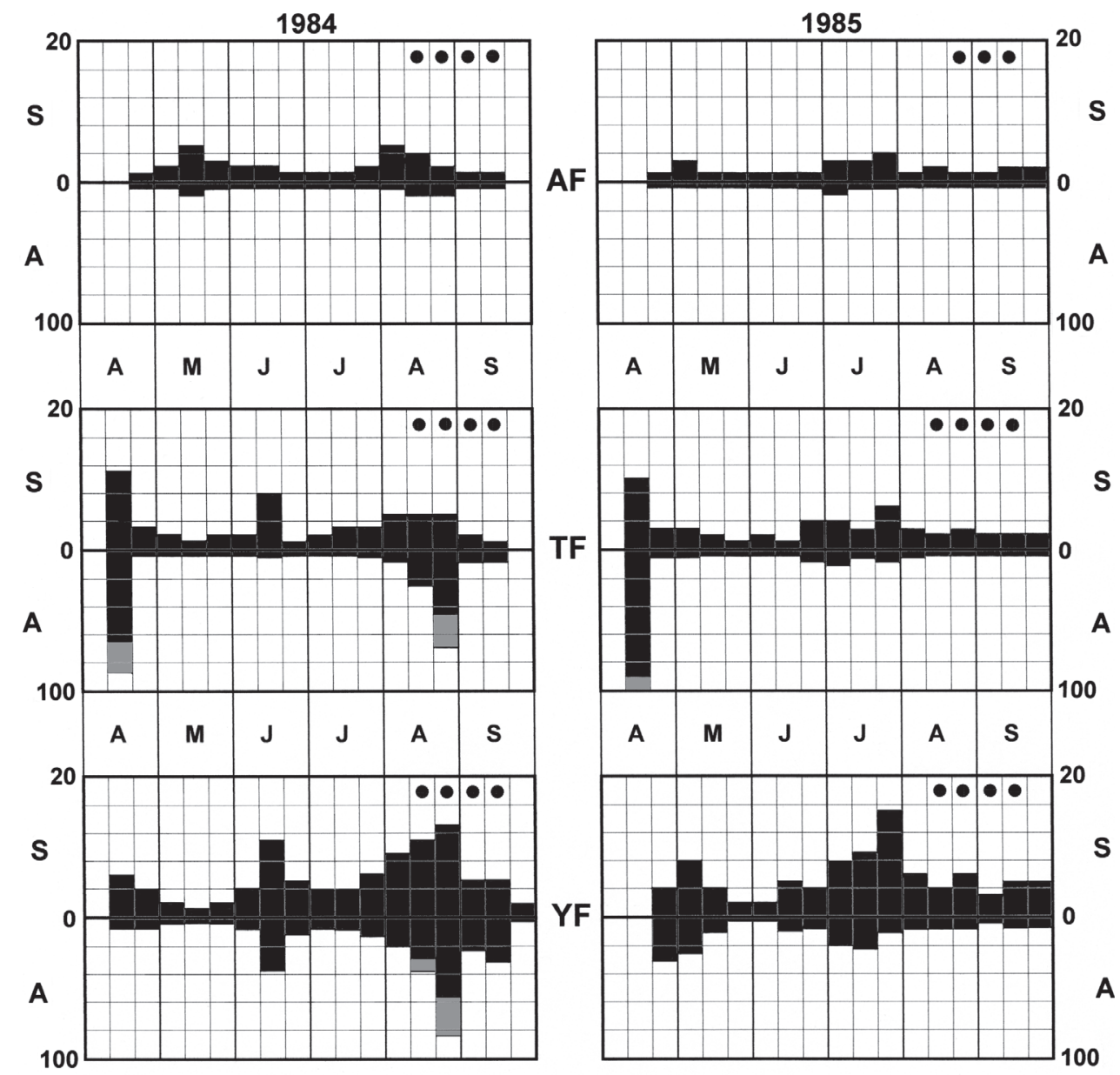

Figure. 1. Seasonal dynamics of bee communities in grassland and heath patches under secondary succession of the Peucedano-Pinetum series in the Torun Basin: YF - young coppice forest, TF - developed coppice forest, AF - forest stand, $\mathrm{S}$ - number of species, A - number of individuals observed within $200 \mathrm{~m} 2$ transect area per $30 \mathrm{~min}$ (grey parts reflect a participation of Apis mellifera), black dots - flowering period of Calluna vulgaris.

\section{References}

Hutcheson K., 1970, A test for comparing diversities based on the Shannon formula, J. Theor. Biol. 29: 151-154.

Kępczyński K., 1980, Mapa potencjalnej roślinności naturalnej w dolinie Wisły na odcinku Włocławek Grudziądz [A map of potential vegetation in the Vistula valley along the section Włocławek - Grudziądz], 1:100 000, unpublished material.

Pawlikowski T., 1985, Zgrupowania dzikich pszczołowatych (Hymenoptera, Apoidea) na kserotermicznych siedliskach wydmowych Kotliny Toruńskiej [Wild bee (Hymenoptera, Apoidea) communities of xerothermic dune habitats in the Torun Basin], Studia Societatis Scientiarum Torunensis, Sec.E 10(4): 1-57.

Pawlikowski T., 1992, Struktura zespołów pszczołowatych (Hymenoptera, Apoidea) na obszarach leśnych Kotliny Toruńskiej [Structure of bee communities (Hymenop- tera, Apoidea) in forest areas of the Torun Basin], UMK, Torun.

Pawlikowski T. \& Kruszyński T., 1997, Aktywność pszczół (Hymenoptera, Apoidea) w odwiedzaniu kwiatów na obszarach leśnych w kotlinie Toruńskiej [Bees' flower visiting activity (Hymenoptera, Apoidea) in forested areas of Torun Basin], Acta Universitatis Nicolai Copernici, Biologia 53, Nauki Mat.-Przyr. 98: 97-106.

Pawłowski B., Zarzycki K., 1972, Szata roślinna Polski, tom I [Vegetation of Poland, vol. 1], PWN, Warszawa.

Pielou E.C., 1966, Shannon's formula as a measure of specific diversity: its use and misuse, Amer. Naturalist 100: 463-465.

Shannon C. E., Weaver W., 1963, The mathematical theory of communication, University of Illinois Press, Urbana.

Symonides E., 1974, Populations of Spergula vernalis Willd. on dunes in the Torun Basin, Ekologia Polska 12: $379-416$. 